2014

\title{
Phytoplankton and Nutrient Dynamics in a Tidally Dominated Eutrophic Estuary: Daily Variability and Controls on Bloom Formation
}

\author{
Ryan E. Morse \\ Old Dominion University \\ Margaret R. Mulholland \\ Todd A. Egerton \\ Old Dominion University \\ Harold G. Marshall \\ Old Dominion University
}

Old Dominion University,mmulholl@odu.edu

Follow this and additional works at: https://digitalcommons.odu.edu/oeas_fac_pubs

Part of the Biogeochemistry Commons, Marine Biology Commons, $\underline{\text { Microbiology Commons, }}$ and the Oceanography Commons

\section{Repository Citation}

Morse, Ryan E.; Mulholland, Margaret R.; Egerton, Todd A.; and Marshall, Harold G., "Phytoplankton and Nutrient Dynamics in a Tidally Dominated Eutrophic Estuary: Daily Variability and Controls on Bloom Formation" (2014). OEAS Faculty Publications. 240. https://digitalcommons.odu.edu/oeas_fac_pubs/240

\section{Original Publication Citation}

Morse, R.E., Mulholland, M.R., Egerton, T.A., \& Marshall, H.G. (2014). Phytoplankton and nutrient dynamics in a tidally dominated eutrophic estuary: Daily variability and controls on bloom formation. Marine Ecology Progress Series, 503, 59-74. doi:

http://dx.doi.org/10.3354/meps10743 


\title{
Phytoplankton and nutrient dynamics in a tidally dominated eutrophic estuary: daily variability and controls on bloom formation
}

\author{
Ryan E. Morse ${ }^{1, *}$, Margaret R. Mulholland ${ }^{1}$, Todd A. Egerton ${ }^{2}$, Harold G. Marshall ${ }^{2}$ \\ ${ }^{1}$ Department of Ocean, Earth, and Atmospheric Sciences, and ${ }^{2}$ Department of Biological Sciences, Old Dominion University, \\ 4600 Elkhorn Avenue, Norfolk, Virginia 23529, USA
}

\begin{abstract}
To better understand nutrient dynamics and factors that promote the initiation of algal blooms, the Lafayette River, a tidal subestuary of Chesapeake Bay that experiences seasonal algal blooms, was sampled daily for a period of $54 \mathrm{~d}$ in the fall of 2005. Three phytoplankton blooms (chl a concentrations exceeding twice the average of monthly measurements from 2000 to 2009) occurred during this period: a mixed bloom of Akashiwo sanguinea and Gymnodinium sp., a monospecific Skeletonema costatum bloom, and a monospecific Gymnodinium sp. bloom. Over the sampling period, nutrient concentrations increased following precipitation events and were elevated between bloom periods but low during blooms. All measured forms of nitrogen $(\mathrm{N})$ were positively correlated with dinoflagellate abundance with a lag time of 3 to $5 \mathrm{~d}$, suggesting a possible triggering effect, although not by any single form of $\mathrm{N}$. Concentrations of $\mathrm{NO}_{2}^{-}$reached $10 \mu \mathrm{M}$ between September and October, indicative of incomplete nitrification. Over a $24 \mathrm{~h}$ period, nutrient concentrations and chl a biomass varied by an order of magnitude ( 0.1 to $1 \mu \mathrm{M} \mathrm{N}$ and 4.5 to $45 \mu \mathrm{g} \mathrm{chl} \mathrm{a} \mathrm{l}^{-1}$, respectively) and were strongly linked to the tidal phase. In the highly eutrophic Lafayette River, when nutrient concentrations are high, phytoplankton blooms appear to be controlled by spring-neap tidal modulation and wind-driven mixing; however, picoplankton abundance does not appear to be linked to the spring-neap tidal cycle.
\end{abstract}

KEY WORDS: Nutrient dynamics - Bloom formation - Dinoflagellates · Estuarine variability · Nitrite $\cdot$ Nitrification $\cdot$ Nitrogen

Resale or republication not permitted without written consent of the publisher

\section{INTRODUCTION}

Since the early 1800s, Chesapeake Bay and its tributaries have experienced a decrease in water quality characterized by decreased overall diversity of diatom species, increased occurrences of anoxic events, increased rates of sedimentation (Cooper \& Brush 1991, 1993, Kemp et al. 2005), and a shift from benthic to pelagic production. The latter has been associated with an increase in the ratio of centric to pennate diatoms and a decrease in water clarity (Cooper $\&$ Brush 1993). Over the last $20 \mathrm{yr}$, sections of the lower Chesapeake Bay and its tributaries have experienced a decrease in phytoplankton diversity and an increase in the abundance of potentially harmful algal taxa (Dauer et al. 2005, Marshall et al. 2005). Algal blooms occur seasonally in Chesapeake Bay and its tributaries, and many of the bloom-forming taxa are potentially harmful or toxin-producing species (Marshall et al. 2005, 2009). Since 2007, major blooms of the harmful dinoflagellate Cochlodinium polykrikoides have occurred annually during summer in the lower Chesapeake Bay and its tributaries (Mulholland et al. 2009, Morse et al. 2011, 2013).

Worldwide, algal blooms appear to be increasing in frequency because of cultural eutrophication (Paerl 1988, Smayda 1990, Pinckney et al. 2001). Eutrophication from nutrient over-enrichment, usually attrib- 
uted to nitrogen $(\mathrm{N})$ and/or phosphorus $(\mathrm{P})$, is often implicated as a causative factor in the formation of both harmful and ecosystem-disruptive algal blooms (EDABs) (Anderson et al. 2002, 2008, Sunda et al. 2006, Heisler et al. 2008). Blooms have also been linked to perturbations in the ratios at which inorganic nutrients are input relative to the Redfield ratio (N:P of 16:1) (Hodgkiss \& Ho 1997). Elevated ratios of dissolved organic carbon (DOC) to dissolved organic nitrogen (DON) (DOC:DON) (Heil et al. 2001, Lomas et al. 2001, Anderson et al. 2002) have also been implicated in bloom formation, while elevated N:silica (Si) or P:Si ratios are thought to select for dinoflagellates over diatoms (Smayda 1990, 1997). In contrast, the development of many EDABs has also been linked to prolonged periods of lower than normal nutrient concentrations (Gobler et al. 2005, Sunda et al. 2006). This may be because of a positive feedback scenario, where a noxious or otherwise unpalatable EDAB species experiences decreased grazing pressure, and thus nutrient recycling and availability are reduced to competing taxa, thereby prolonging bloom duration (Sunda et al. 2006). While it is certain that nutrients play a major role in the formation of algal blooms, no single nutrient or combination of nutrients has emerged as a causative factor for the formation of blooms, and the environmental conditions promoting bloom development are still poorly understood (Anderson et al. 2002).

Because algal blooms are seldom visible until cell numbers exceed $10^{6}$ cells $\mathrm{l}^{-1}$, blooms in the natural environment are usually sampled only after the bloom is already well established, nutrients have been drawn down by the bloom organism, and competing taxa are absent. Rarely are the conditions leading up to or promoting bloom formation captured in sampling programs because the temporal resolution of sampling is insufficient. Consequently, most reports characterize fully mature or even senescent blooms; thus, factors promoting blooms remain largely unknown.

In coastal and estuarine environments, physical forcing from tides and estuarine circulation play a major role in the distribution and patchiness of phytoplankton populations (Cloern et al. 1985, 1989). Tidal forcing, estuarine circulation, and the behavior of many bloom-forming organisms (e.g. vertical migration) all contribute to temporal and spatial patchiness of blooms. Tidal transport and advection tend to 'smear' phytoplankton patches horizontally along estuarine gradients (Lucas et al. 1999). Further, physical boundaries within an estuary can interrupt and deflect density and wind-driven flows, often result- ing in the formation of complex eddy circulation (Geyer \& Signell 1992, Shen et al. 1999). The importance of tidal transport processes on estuarine phytoplankton populations is highlighted in continuous chl a monitoring programs and timeseries records, where chl a concentrations vary in conjunction with the tidal stage, and the chl a maximum often occurs at a particular stage of the tidal cycle (Mallin et al. 1999, Li \& Smayda 2001). The transient and ephemeral nature of these processes, which occur on tidal and subtidal timescales, are rarely captured in fixedstation monitoring programs in which samples are collected weekly to monthly (Dustan \& Pinckney 1989, Trigueros \& Orive 2000). Consequently, most monitoring programs are temporally and spatially insufficient to capture blooms and their progression from initiation to senescence, and small-scale, highfrequency targeted studies on bloom initiation are required to gain a better understanding of the processes involved in the formation of algal blooms.

To better understand the timescales of variability in phytoplankton populations and conditions promoting algal blooms, we sampled the Lafayette River, a shallow, eutrophic subtributary of the lower Chesapeake Bay where algal blooms regularly occur, at a fixed station on a daily basis at the same phase of the tidal cycle for a period of $54 \mathrm{~d}$ in fall of 2005, a period when blooms routinely occur (Fig. 1). Ambient dissolved inorganic nitrogen (DIN) concentrations in the Lafayette River are often $>10 \mu \mathrm{M}$, and the concentration of dissolved inorganic phosphorus (DIP) is typically above $1 \mu \mathrm{M}$. Between 2000 and 2009, the Chesapeake Bay monitoring program station LFB01 in the Lafayette River had an average DIN concentration of $5.8 \mu \mathrm{M}(\mathrm{SD}=8.8 \mu \mathrm{M})$, and the average DIP concentration at this station was $0.74 \mu \mathrm{M}(\mathrm{SD}=$ $0.84 \mu \mathrm{M}$ ) (Chesapeake Bay Program 2009, www. chesapeakebay.net/data_waterquality.aspx). The Lafayette River has a water residence time of 1 to $4 \mathrm{mo}$, depending on the amount of rain in a given year (White 1972) or event-scale processes such as nor'easters and tropical storms, which may modulate the residence time (Paerl et al. 2006). The combination of a long residence time and high nutrient loads favors the growth of dinoflagellates (Margalef 1978, Sellner et al. 2001), making this an ideal location to observe algal bloom dynamics.

The goal of this study was to identify factors promoting the initiation of algal blooms and to relate changes in phytoplankton community structure with nutrient concentrations on short timescales characteristic of developing blooms. Sampling on a daily basis allowed for higher temporal resolution of 
phytoplankton populations, nutrient dynamics, and physical forcing than most monitoring programs afford.

\section{METHODS}

\section{4 h tidal phase sampling}

To understand how algal abundance and nutrient dynamics are controlled by tidal forcing, we sampled a tidal subestuary of the lower Chesapeake Bay, the Lafayette River (Fig. 1; Center for Coastal Physical

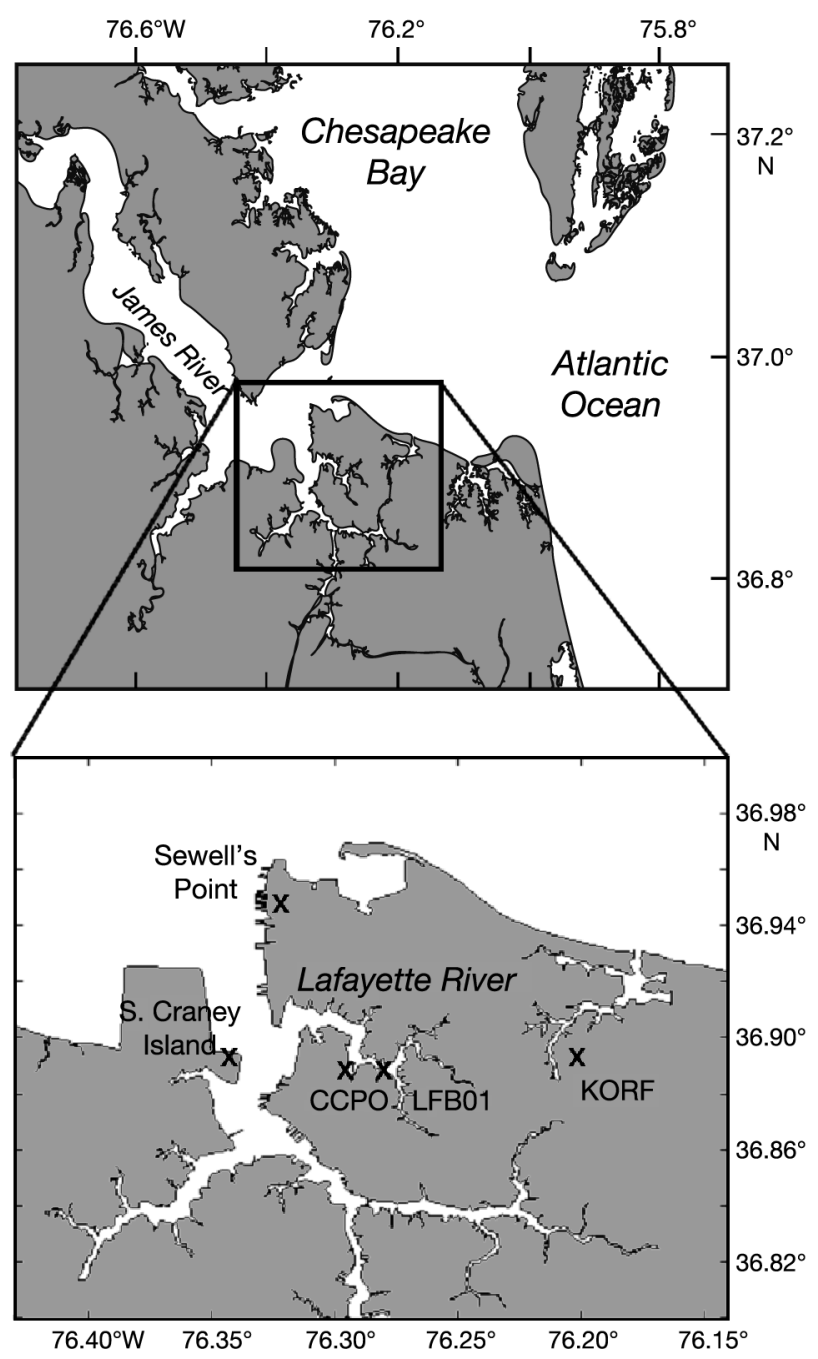

Fig. 1. Study area, showing sampling sites on the Lafayette River at the Center for Coastal Physical Oceanography (CCPO), Norfolk International Airport (KORF), NOAA Physical Oceanography Real-Time System (PORTS) station at Sewell's Point, NOAA PORTS station at S. Craney Island, and Virginia Department of Environmental Quality water quality station LFB01
Oceanography, CCPO), on an hourly basis for a period of $24 \mathrm{~h}$. A Hydrolab DataSonde $4 a$ water quality multiprobe was used to measure conductivity and water temperature at each sampling time. Water was collected, beginning on July 18, 2005, at 06:00 h local time, in an acid-cleaned carboy. In the lab, water was withdrawn and filtered onto Whatman GF/F glass fiber filters for chl $a$ analysis. Nutrient samples were collected after filtration through $0.2 \mu \mathrm{m}$ Supor filters. Nutrient and chl a samples were immediately frozen and stored in a freezer until analysis. Tidal height data were obtained from the NOAA Physical Oceanography Real-Time System (PORTS) station at Sewell's Point in the Elizabeth River (Fig. 1). The distance between the sampling site in the Lafayette River and the NOAA Sewell's Point tide gauge is $<12 \mathrm{~km}$, and on average, tidal height predictions for the Lafayette River lag those for Sewell's Point by approximately $20 \mathrm{~min}$. Since data were collected on an hourly basis, the time of measured low water at Sewell's Point and low salinity in the Lafayette River are offset by approximately $1 \mathrm{~h}$.

\section{Daily tidal phase sampling}

Based on the results from the hourly sampling, daily sampling of surface water from the Lafayette River was timed to coincide with the highest observed algal biomass, which was at the incoming tide approximately $2 \mathrm{~h}$ after the low tide in the Lafayette River. Samples were only collected during daylight hours. When the flood tide occurred at night, the sampling interval was extended approximately $12 \mathrm{~h}$ to coincide with the subsequent flood tide during daylight; this happened on August 22 and September 2 and 7. Prior to water sampling, dissolved oxygen, salinity, and water temperature were measured in situ using a Hydrolab DataSonde $4 a$ water quality multiprobe. Because of the arrangement of the sensors on the sonde, all parameters were measured at the bottom of the water column. The average depth of the water during the sampling period was $1 \mathrm{~m}$. Water samples were collected from the surface using an acid-cleaned bucket, placed into a 201 acidcleaned polycarbonate carboy, and transported to the laboratory $<3 \mathrm{~km}$ away.

\section{Sample handling and analyses}

Once at the laboratory, water samples were kept well mixed by adding a magnetic stir bar to the car- 
boys and gently stirring their contents. Samples for nutrient analyses were immediately filtered through a $0.2 \mu \mathrm{m}$ Pall sterile microculture capsule using a peristaltic pump. The filtrate was placed into acidcleaned bottles and stored frozen until analysis. $\mathrm{NO}_{3}{ }^{-}$ $+\mathrm{NO}_{2}{ }^{-}, \mathrm{NO}_{2}{ }^{-}$, urea, $\mathrm{PO}_{4}{ }^{-3}$, and silicate $\left(\mathrm{SiO}_{4}{ }^{4-}\right)$ were measured using an Astoria Pacific nutrient autoanalyzer according to manufacturer specifications and consistent with the colorimetric techniques outlined by Parsons et al. (1984). Ammonium $\left(\mathrm{NH}_{4}{ }^{+}\right)$concentrations were measured by the phenolhypochlorite method of Solorzano (1969). Total dissolved nitrogen (TDN) and total dissolved phosphorus (TDP) were analyzed at Old Dominion University's Water Quality Laboratory, following the standard procedures and protocol outlined for the Chesapeake Bay water quality monitoring program (http://archive.chesapeakebay.net/pubs/quality_assurance/doc-EPA903R-96-006.pdf). DON was calculated as the difference between TDN and DIN. Dissolved organic phosphorus (DOP) was calculated as the difference between TDP and DIP. Nutrient concentrations that were below the detection limit were assigned values of the detection limit for statistical purposes.

Whole water samples $(500 \mathrm{ml})$ were preserved with Utermohl's modified Lugol's solution for enumeration of microplankton and nanoplankton and with $1 \%$ glutaraldehyde (final concentration) for enumeration of picoplankton. Phytoplankton were quantified microscopically as described by Marshall \& Nesius (1996), and autotrophic picoplankton ( 0.2 to $2 \mu \mathrm{M})$ were enumerated via epifluorescent microscopy following filtration onto polycarbonate Nuclepore filters with a pore size of $0.2 \mu \mathrm{m}$ (Affronti \& Marshall 1994, Marshall \& Nesius 1996). Chl a samples were collected onto glass fiber filters (Whatman GF/F) and stored frozen until analysis using the non-acidification fluorometric technique of Welschmeyer (1994) within 3 wk of collection. Phytoplankton blooms are hereafter defined as when the cell abundance of a single taxon exceeded $0.5 \times 10^{6}$ cells $^{-1}$ for a period of $3 \mathrm{~d}$ or longer and/or daily chl a concentrations exceeded $44 \mathrm{\mu g} \mathrm{l}^{-1}$, twice the average chl a concentration for the nearby Chesapeake Bay monitoring program station LFB01 (Fig. 1) from 2000 to 2009 (Morse et al. 2011).

\section{Correlation and statistical analyses}

Phytoplankton taxonomic abundance (as phyla) was compared to nutrient concentrations by calculating the cross-correlation function using The Math-
Works MATLAB software, which follows the crosscorrelation function equation given by Box et al. (2008). Because phytoplankton growth rates are on the order of days, a time lag in the response of phytoplankton abundance to nutrient loading events was expected. Therefore, we compared nutrient concentrations with phytoplankton abundance at $1 \mathrm{~d}$ intervals ranging from $7 \mathrm{~d}$ previous through $7 \mathrm{~d}$ forward in time. Additionally, to explore the effect of autocorrelation among nutrients, the autocorrelation function of each nutrient compound was plotted for a $7 \mathrm{~d}$ period. The $95 \%$ CI was calculated by the program using 2 SDs of either the cross-correlation function or the autocorrelation function.

\section{Meteorological and supplementary data}

Atmospheric pressure and tidal height data were obtained from the NOAA PORTS station at Sewell's Point (Fig. 1, Sewell's Point), and wind speed data were obtained from the NOAA PORTS Craney Island station near the mouth of the Lafayette River (Fig. 1, S. Craney Island). Precipitation data were obtained from Norfolk International Airport (Fig. 1, KORF). Surface nutrient and chl a data for the Virginia Department of Environmental Quality (VADEQ) Lafayette River station LFB01 (approximately $1 \mathrm{~km}$ upriver from the CCPO sampling site) from 2000 to 2009 were obtained from the Chesapeake Bay Program's data hub (http://chesapeakebay.net/data/downloads/cbp_water _quality_database_1984_present).

\section{RESULTS}

\section{Hourly nutrient and chl a variability}

Nutrient and chl a concentrations were measured hourly over a $24 \mathrm{~h}$ period from July 18 to 19 , 2005, in the Lafayette River to determine the effect of tides on these water quality parameters. There was no precipitation during the sampling period, and the Lafayette River has no freshwater tributaries or inputs other than runoff from precipitation. The Lafayette River experiences semidiurnal tides, and the concentrations of both chl $a$ and nutrients appear to have semidiurnal maxima and minima linked to the tidal phase (Fig. 2).

Over the $24 \mathrm{~h}$ sampling period, $\mathrm{NO}_{3}{ }^{-}+\mathrm{NO}_{2}{ }^{-}$concentrations in the Lafayette River varied by an order of magnitude, chl a varied by a factor of 8 , and this variability appeared to be tidally controlled 
Fig. 2. (a) Hourly chl a ( $\left.\mu \mathrm{g} \mathrm{l}^{-1}\right)$ and $\mathrm{NO}_{3}{ }^{-}+\mathrm{NO}_{2}{ }^{-}\left(\mathrm{NO}_{\mathrm{x}}, \mu \mathrm{M}\right)$ measured in the Lafayette River at the Center for Coastal Physical Oceanography (CCPO); $\mathrm{NO}_{3}{ }^{-}$and $\mathrm{NO}_{2}^{-}$ displayed similar concentrations and trends between time points and, thus, are reported as $\mathrm{NO}_{\mathrm{x}}$ for clarity. (b) Hourly tidal height (m above mean lower low water, MLLW) measured at Sewell's Point in the Elizabeth River and salinity measured in the Lafayette River at CCPO. All measurements made on July 18 to 19,2005

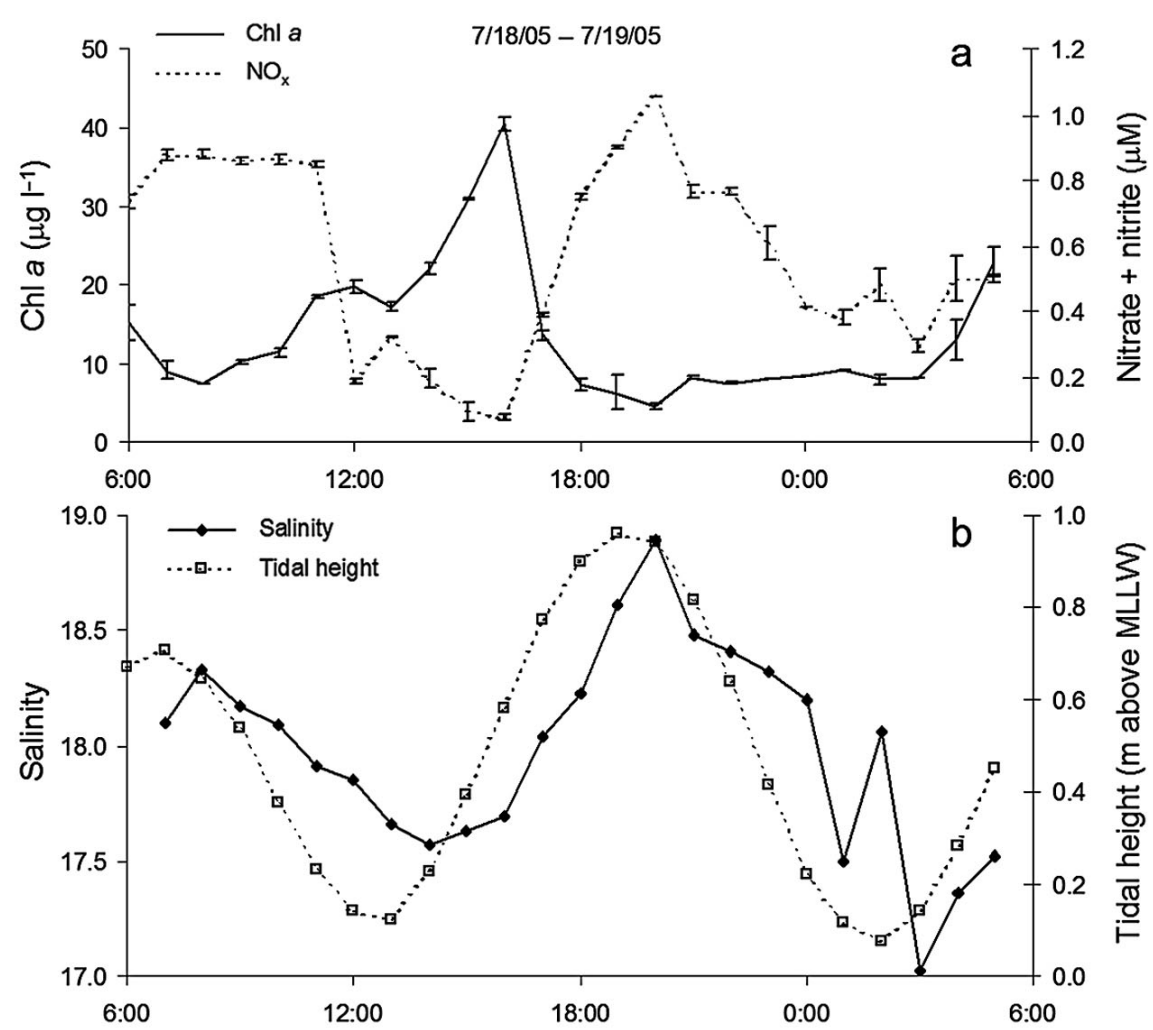

(Fig. 2a,b). Chl a concentrations were highest approximately 2 to $3 \mathrm{~h}$ after low tide (Fig. 2a,b). Nutrient concentrations were highest at maximum flood tide, when chl a concentrations were low. The salinity measured in the Lafayette River lagged behind tidal height observations for Sewell's Point by approximately $1 \mathrm{~h}$ (Fig. 2b). Based on the chl a variability observed over the tidal cycle, we elected to collect samples for our $54 \mathrm{~d}$ daily study (August 15 to October 8,2005 ) approximately $2 \mathrm{~h}$ after the predicted low tide in the Lafayette River, when $\mathrm{chl} a$, and thus phytoplankton biomass, was highest.

\section{Phytoplankton abundance}

Between August 15 and October 8, 2005, 3 major blooms occurred in the Lafayette River (Fig. 3a). The first bloom, a mixed-species dinoflagellate bloom

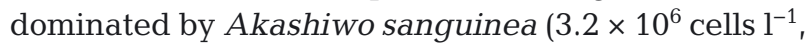
$>88.4 \%$ total abundance), was already in progress at the start of the daily sampling period on August 15, 2005. However, on August 16, an unidentified Gymnodinium sp. was the dominant species $\left(0.5 \times 10^{6}\right.$ cells $\mathrm{l}^{-1}$ ), comprising 48 and $42 \%$ of the total phytoplankton abundance on August 16 and 17, respectively (Fig. 3a). At this time, concentrations of dissolved urea, $\mathrm{NH}_{4}{ }^{+}, \mathrm{NO}_{3}{ }^{-}$, and $\mathrm{NO}_{2}{ }^{-}$were at or near their limits of analytical detection (Fig. 3b). Subsequently, dinoflagellate abundance decreased until

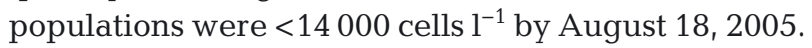
At this time, dissolved $\mathrm{N}$ concentrations increased, and $\mathrm{NO}_{2}{ }^{-}$and $\mathrm{NH}_{4}{ }^{+}$concentrations reached 7.2 and $10.4 \mu \mathrm{M}$, respectively, by August 24 (Fig. 3a,b). Diatoms and cryptophytes comprised $86 \%$ of the phytoplankton at this time, but total phytoplankton abundance was still $<1.0 \times 10^{6}$ cells $1^{-1}$.

The second bloom occurred between August 28 and September 3, 2005. Beginning about August 25 and between August 27 and September 3, the relative abundance of diatoms and cryptophytes increased, and the greatest total phytoplankton abundance observed during the study period occurred on September 1, at $1.2 \times 10^{7}$ cells $1^{-1}$ (Fig. 3a). Diatoms were the dominant taxa on August 28 and 31 and September 1, while cryptophytes were dominant on August 29 to 30 (Fig. 3c). Between August 31 and September 3, Skeletonema costatum was the dominant phytoplankter enumerated in our samples (Fig. 3a,c). Diatoms comprised $96.9 \%$ of the total phytoplankton abundance on August 31, with $9.2 \times$ $10^{6}$ diatom cells $1^{-1}$, and increased to $10.7 \times 10^{6}$ diatom cells $1^{-1}$ on September 1, when they comprised $89.7 \%$ of the phytoplankton population (Fig. 3a,c). Diatoms remained abundant through September 5. As diatoms and cryptophytes increased in abun- 

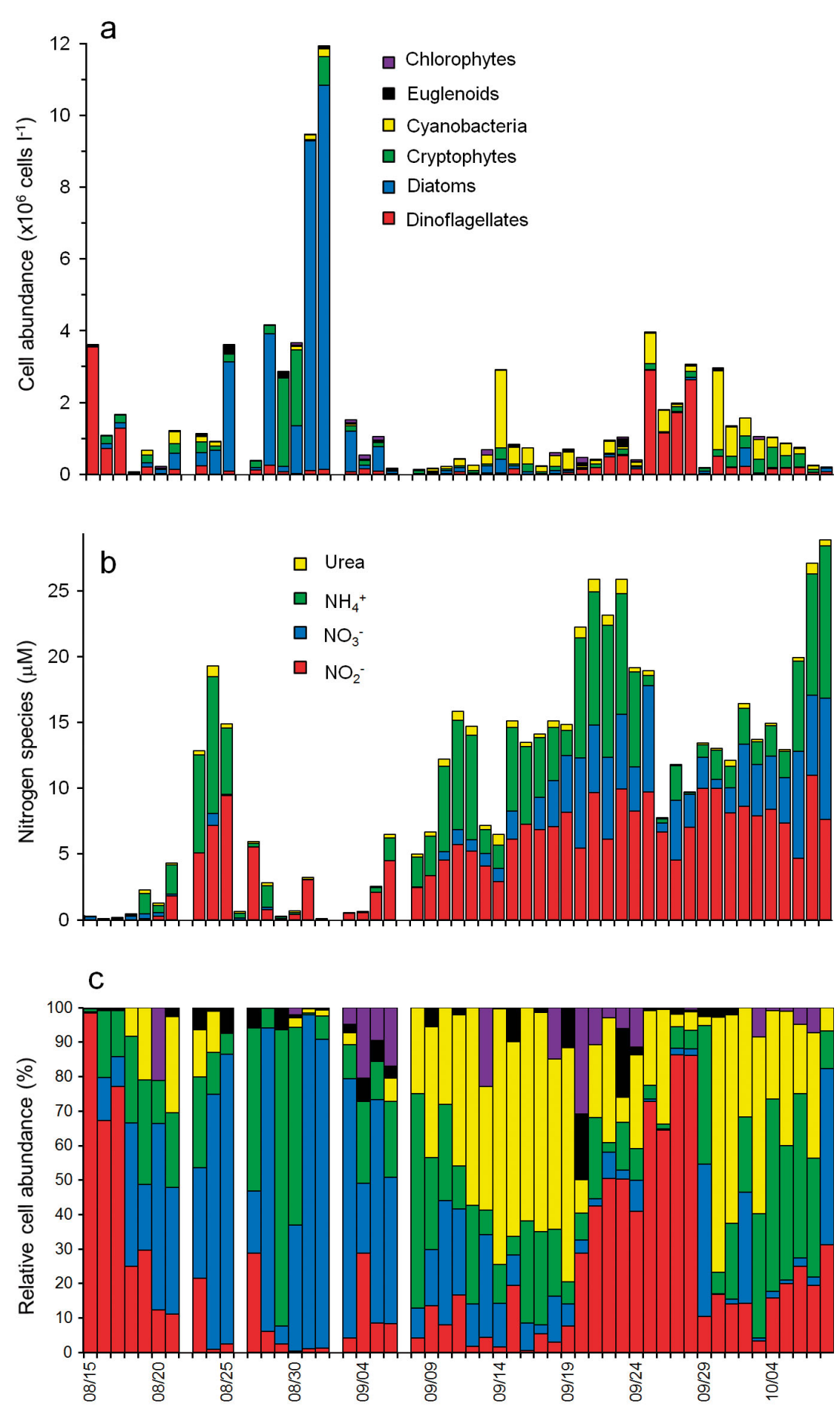

Fig. 3. (a) Stacked daily abundance of cyanobacteria and phytoplankton taxa

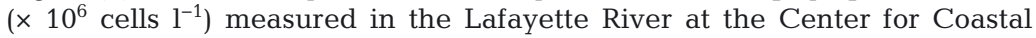
Physical Oceanography (CCPO). (b) Stacked concentrations of dissolved inorganic nitrogen species $\left(\mathrm{NO}_{3}{ }^{-}, \mathrm{NO}_{2}{ }^{-}\right.$, ammonium $\left.\left[\mathrm{NH}_{4}{ }^{+}\right]\right)$and urea $(\mu \mathrm{M}$ measured at CCPO). (c) Relative taxonomic abundance of plankton expressed as a daily percent of the total cell count (legend is the same as in [a]). Dates given as mm/dd in 2005 dance, dissolved $\mathrm{N}$ concentrations became depleted, and $\mathrm{NO}_{2}^{-}$or $\mathrm{NH}_{4}{ }^{+}$ were the dominant forms of dissolved $\mathrm{N}$ in the system (Fig. 3b).

After September 5, the relative abundance of filamentous cyanobacteria increased (Fig. 3c), although the total cell number was much lower than that observed during the diatom bloom (Fig. 3a). At the same time, on September 6, dissolved $\mathrm{N}$ concentrations increased and remained $>5.0 \mu \mathrm{mol} \mathrm{l}^{-1}$ for the duration of the study (Fig. 3b).

The third bloom occurred between September 25 and 28, 2005. Beginning September 20, dinoflagellate relative abundance increased, and dinoflagellates comprised $72.9 \%$ of the phytoplankton community by September 25, with an unidentified Gymnodinium sp. reaching an abundance of $1.4 \times 10^{6}$ cells $1^{-1}$ and dominating the assemblage (Fig. 3a,c). On September 28, the abundance of Gymnodinium sp. reached $2.0 \times 10^{6}$ cells $1^{-1}$, while cryptophyte abundance was at or near its lowest level during the 54 d study.

Picoplankton abundance was greatest in late August, with a maximum abundance of $2.8 \times 10^{9}$ cells $\mathrm{l}^{-1}$ on August 21 (Fig. 4a). Picoplankton abundance generally declined throughout the study period, with the minimum abundance occurring on October 6 , at

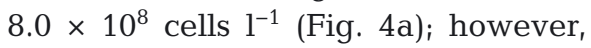
brief fluctuations in picoplankton abundance (lasting 2 to $4 \mathrm{~d}$ ) occurred at approximately weekly timescales throughout the study period (Fig. 4a).

\section{Nutrient concentrations}

DIN $\left(\mathrm{NO}_{2}{ }^{-}, \mathrm{NO}_{3}{ }^{-}\right.$, and $\left.\mathrm{NH}_{4}{ }^{+}\right)$and urea concentrations were at or near the limits of detection at the start of the study, between August 15 and 18 (Fig. 3b), when dinoflagellate abundance was high (Fig. 3a). $\mathrm{NO}_{2}{ }^{-}$concentrations increased after August 20, reaching nearly $7 \mu \mathrm{mol} \mathrm{l^{-1 }}$ on August 25. $\mathrm{NH}_{4}{ }^{+}$concentrations also increased, 
Fig. 4. (a) Picoplankton abundance

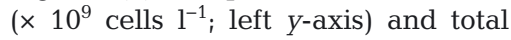
microplankton and nanoplankton abundance $\left(\times 10^{6}\right.$ cells $\mathrm{l}^{-1}$; right $y$ axis). (b) Dissolved organic nitrogen (DON, $\mu \mathrm{M} \mathrm{N}$; left $y$-axis) and dissolved inorganic phosphorus (DIP, $\mu \mathrm{M}$ $\mathrm{P})$ and dissolved organic phosphorus

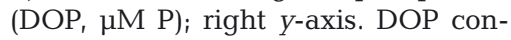
centrations below detection limit $(0.027 \mu \mathrm{M})$ were assigned values of the detection limit for statistical purposes. Dates given as mm/dd in 2005
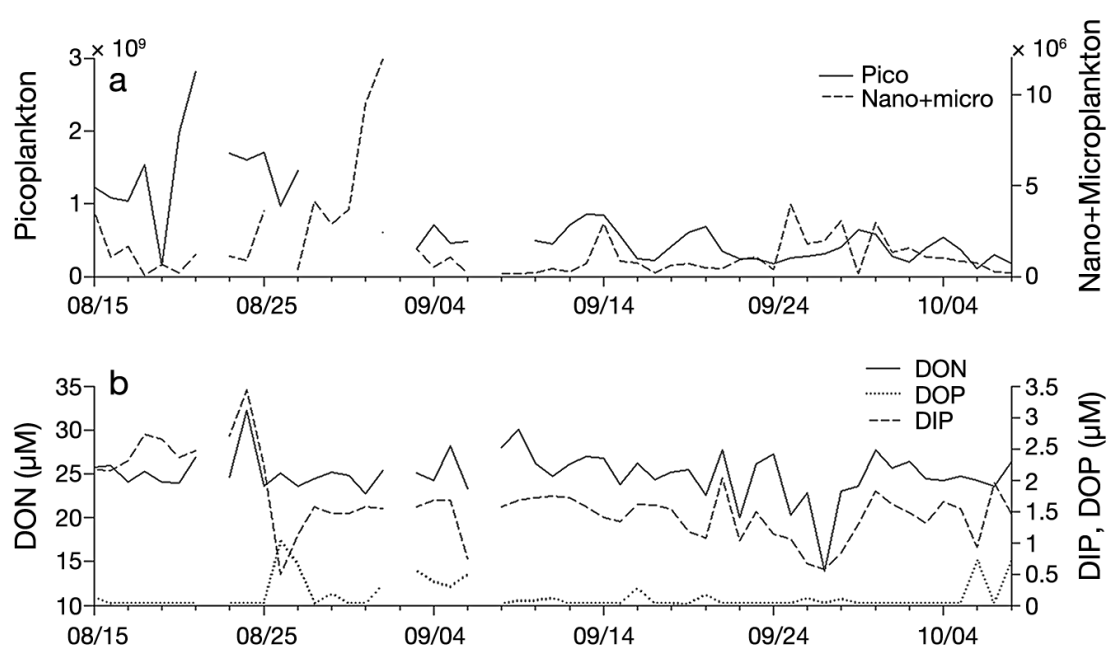

but then both $\mathrm{NO}_{2}{ }^{-}$and $\mathrm{NH}_{4}{ }^{+}$were drawn down as phytoplankton biomass increased between August 24 and September 3 (Fig. 3a,b). Beginning September $5, \mathrm{NO}_{2}{ }^{-}$concentrations increased from near the detection limit $\left(0.02 \mu \mathrm{mol} \mathrm{l^{-1 }}\right)$ to $10 \mu \mathrm{mol} \mathrm{l^{-1 }}$ by the end of the study period (Fig. $3 \mathrm{~b}$ ).

$\mathrm{NO}_{3}{ }^{-}$concentrations were generally low relative to other forms of $\mathrm{N}$, typically $<2 \mu \mathrm{mol} \mathrm{l}^{-1}$ and $<2 \%$ of TDN until September 14 (Figs. 3b \& 4b). In mid-September, $\mathrm{NO}_{3}{ }^{-}$concentrations increased, reaching a maximum of $9 \mathrm{\mu mol} \mathrm{l}^{-1}$ by October 8 , and $\mathrm{NO}_{3}{ }^{-}$represented a substantial fraction of the DIN pool (up to $30 \%$ ) during the latter third of the study period (Fig. 3b). $\mathrm{NO}_{3}{ }^{-}$concentrations were lower during the September dinoflagellate bloom, when cyanobacterial abundance was also high (Fig. 3a,c).

Concentrations of $\mathrm{NH}_{4}^{+}$ranged from below the detection limit $\left(<0.02 \mu \mathrm{mol} \mathrm{l}^{-1}\right)$ to $>10 \mu \mathrm{mol} \mathrm{l^{-1 }}$ and were highly variable over the course of the $54 \mathrm{~d}$ study. The highest $\mathrm{NH}_{4}{ }^{+}$concentrations were observed between bloom periods, while large decreases in $\mathrm{NH}_{4}{ }^{+}$concentrations occurred during periods when phytoplankton cell abundance increased (Fig. 3a,b). $\mathrm{NH}_{4}{ }^{+}$concentrations were highest prior to the diatom bloom at the end of August (10.4 $\mu \mathrm{mol} \mathrm{l}^{-1}$ on August 24) and prior to and after the September dinoflagellate bloom (10.1 $\mathrm{mmol} \mathrm{l}^{-1}$ on September 21 to 22 and $11.6 \mu \mathrm{mol} \mathrm{l}^{-1}$ on October 8). $\mathrm{NH}_{4}{ }^{+}$concentrations were near or below the detection limit on August 31 during the diatom bloom and during the dinoflagellate blooms on August 15 to 16 and September 28.

Urea concentrations were low throughout the sampling period, with a maximum concentration of $1 \mu \mathrm{mol} 1^{-1}$ on September 23 (Fig. 3b). Urea concentrations comprised only a small portion of the TDN pool at any given time (generally $<1 \%$ of TDN, but always
$<2.5 \%$ of $\mathrm{TDN}) . \mathrm{SiO}_{4}^{4-}$ concentrations were high, ranging from 30 to $70 \mu \mathrm{mol} \mathrm{l}^{-1}$ throughout the study period (data not shown), and the ratio of dissolved $\mathrm{SiO}_{4}{ }^{4-}$ to DIN was always $>1 . \mathrm{SiO}_{4}{ }^{4-}$ concentrations decreased from $80 \mu \mathrm{mol} \mathrm{l}^{-1}$ to $60 \mu \mathrm{mol} \mathrm{l^{-1 }}$ as a diatom bloom formed in late August but were never depleted (data not shown).

DIP concentrations were also relatively high throughout the study period, ranging from 0.5 to $3.5 \mu \mathrm{mol} \mathrm{l}^{-1}$, well above the limit of analytical detection (Fig. 4b). At the onset of the study in midAugust, DIP concentrations were higher (maximum of $3.4 \mu \mathrm{mol} \mathrm{l}^{-1}$ ) but decreased by nearly a factor of 2 following the diatom bloom in late August and remained lower for the remainder of the study period (average $1.6 \pm 0.6 \mu \mathrm{mol} \mathrm{l}^{-1}$ ) (Figs. 3a \& 4b)

DON concentrations did not change much over the $54 \mathrm{~d}$ study period (average $24.9 \pm 2.6 \mu \mathrm{mol} \mathrm{l}^{-1}$ ), with one exception; DON concentrations were lower during the dinoflagellate bloom from September 25 to 28 , and the lowest concentration was observed on September 27 (13.9 $\mu_{\mathrm{mol} \mathrm{l}}^{-1}$ ) (Figs. 3a \& 4b). DOP concentrations were lower (maximum of $1.0 \mu \mathrm{mol}$ $\mathrm{l}^{-1}$ ) than DIP concentrations and were often below the limit of analytical detection (Fig. 4b). Because the DOP concentrations were so low and the variance was so great, patterns in DOP concentrations relative to phytoplankton abundance could not be elucidated.

\section{Meteorological and physical controls on estuarine variability}

Between August 6 and 12, prior to the start of the daily sampling, $11.5 \mathrm{~cm}$ of precipitation was measured at KORF (data not shown). Precipitation oc- 


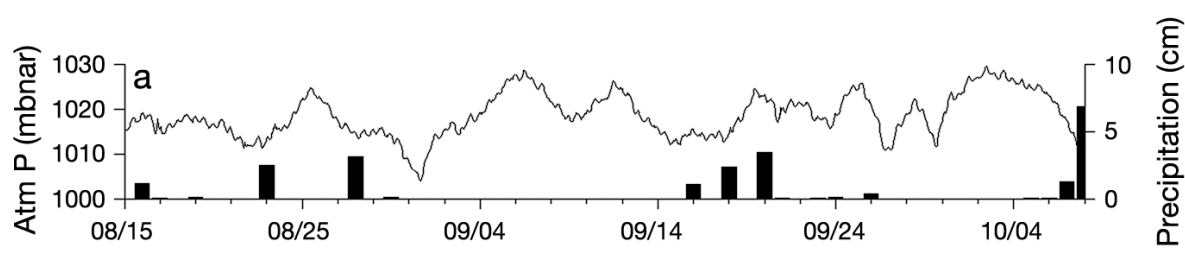

Fig. 5. (a) Atmospheric pressure (Atm $\mathrm{P}$, mbar) recorded at

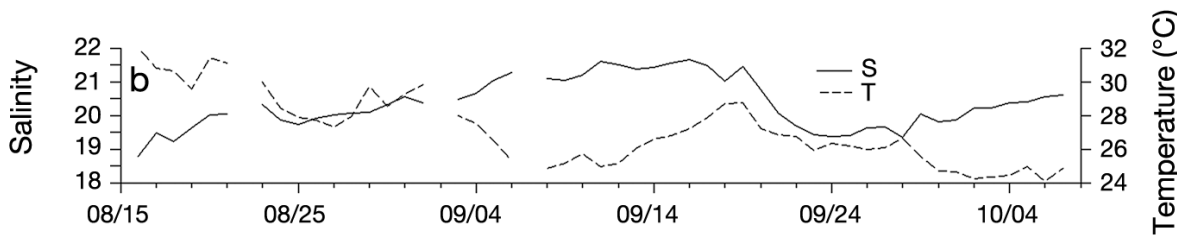
Sewell's Point and daily precipitation $(\mathrm{cm})$ measured at Norfolk International Airport. (b) Salinity and temperature $\left({ }^{\circ} \mathrm{C}\right)$ measured at the Center for Coastal Physical Oceanography. (c) Tidal range (m) and tidal residual (measured; predicted height, $\mathrm{m}$ ) recorded at

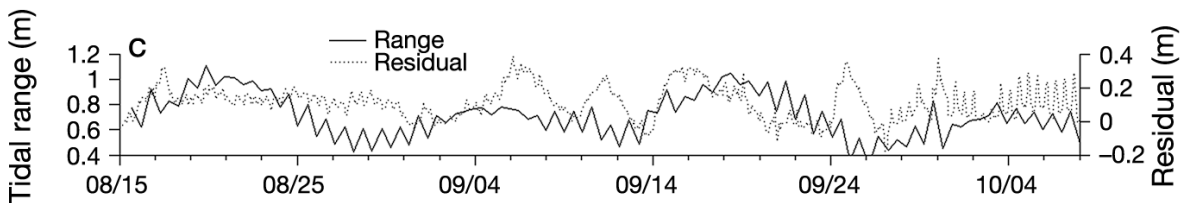
Sewell's Point. Dates given as $\mathrm{mm} / \mathrm{dd}$ in 2005. Breaks in the data of (b) are due to the unavailabillity of the sonde on these days

curred on August 15 and $16(1.1 \mathrm{~cm})$ after a dinoflagellate bloom had formed in the Lafayette River (Figs. 3a \& 5a), on August $23(2.5 \mathrm{~cm})$ and $28(3.1 \mathrm{~cm})$, between September 16 and $20(6.8 \mathrm{~cm})$, and between October 6 and $8(8.0 \mathrm{~cm})$ (Fig. 5a). Nutrient concentrations increased following rainfall events, except on August 15 (Figs. 3b \& 5a).

The wind was predominantly from the northeast during 4 periods: August 24 to 25, September 5 to 16, September 24, and September 29 (Fig. 6a), during which times the chl a concentration generally decreased (Fig. 6b), often resulting in the end of a bloom. As the remnants of Hurricane Katrina (downgraded to a tropical storm) passed to the west of the region beginning August 30, the wind speed increased and the direction shifted from the south to the southwest as the atmospheric pressure decreased to $<1005$ mbar on August 31 (Figs. 5a \& 6a). This period of high wind coincided with a decrease in the abundance of cryptophytes and an increase the abundance of diatoms; a bloom of Skeletonema costatum followed the August 30 to 31 wind event (Figs. 3a,c \& 6a). There was a prolonged period of high winds beginning September 3 as a highpressure system moved through the region following the remnants of Hurricane Katrina (Figs. 5a \& 6a), and this corresponded to the demise of the diatom bloom (Fig. 6b). The high winds blew predominantly from the northeast during this period (Fig. 6a) and resulted in a positive tidal residual at Sewell's Point in the Elizabeth River (Fig. 5c). This positive tidal residual also coincided with an increase in salinity in the Lafayette River after September 5 (Fig. 5b). In addition, the water temperature in the Lafayette River cooled by $4^{\circ} \mathrm{C}$ during this event (Fig. 5b).

The winds increased again from September 10 to 12 as another high-pressure system passed through the region, and the winds were again predominantly

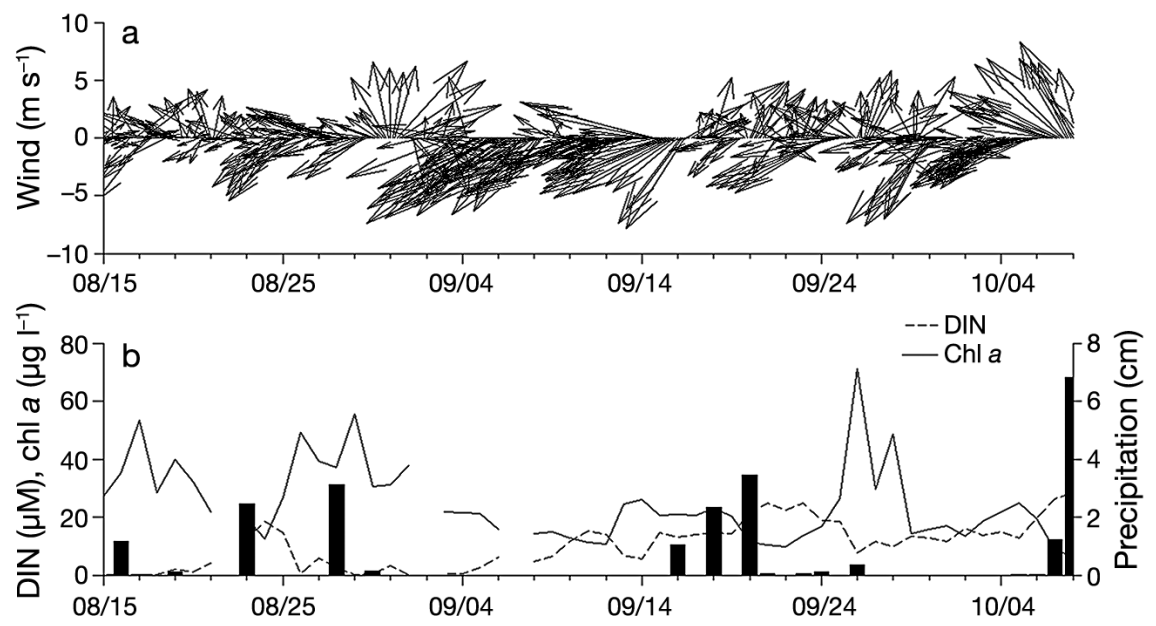

Fig. 6. (a) $3 \mathrm{~h}$ mean wind vector velocity $\left(\mathrm{m} \mathrm{s}^{-1}\right)$ measured at Craney Island. (b) Chl a $\left(\mu \mathrm{g} \mathrm{l^{-1 }}\right)$ and dissolved inorganic nitrogen concentration (DIN, $\mu \mathrm{M} \mathrm{N}$; left $y$ axis) measured at the Center for Coastal Physical Oceanography and daily precipitation $(\mathrm{cm}$; right $y$-axis) measured at Norfolk International Airport. Dates given as $\mathrm{mm} / \mathrm{dd}$ in 2005 
from the northeast (Figs. 5a \& 6a). A third high-wind event occurred as the effects from Hurricane Ophelia passed over the Outer Banks of North Carolina and moved off the coast of Virginia from September 14 to 16 (Figs. 5a \& 6a). Although below hurricane strength, this storm system was associated with substantial precipitation between September 16 and 20 (Fig. 5a). The predominantly northeasterly winds associated with this system again resulted in a positive tidal residual in the Elizabeth River at Sewell's Point (Figs. 5c \& 6a) as well as increased salinity and water temperature in the Lafayette River (Fig. 5b). Water temperature and salinity in the Lafayette River decreased abruptly on September 20 (Fig. 5b) as the remnants of Hurricane Ophelia passed by the region, resulting in $>3 \mathrm{~cm}$ of precipitation (Fig. 5a). Two more high-wind events occurred in late September and one occurred in October, but the duration of the high winds was short and the direction from which they came was not constant for $>24 \mathrm{~h}$ (Fig. 6a); however, the dinoflagellate bloom in September ended as the winds increased in intensity from the northeast on September 29.

Spring-neap tidal modulation appeared to affect nanoplankton and microplankton abundance more than picoplankton abundance (Figs. 4a \& 5c). Total phytoplankton (nanoplankton plus microplankton) abundance was higher during neap tides and lowest during spring tides. The dinoflagellate blooms in August and September, the diatom bloom in August, and the high cyanobacterial abundance in September all occurred during neap tides (Figs. 3a \& 5c). Both the maximum and minimum picoplankton abundances occurred during spring tides. Picoplankton abundance was not as strongly controlled by the tidal cycle, and their abundance appeared to cycle on a 7 to $9 \mathrm{~d}$ basis regardless of the tidal phase (Figs. $4 \mathrm{a}$ $\& 5 \mathrm{c})$.

\section{DISCUSSION}

Near-monospecific algal blooms are now common occurrences in Chesapeake Bay and its tidal tributaries, as well as other highly eutrophic estuarine systems worldwide. However, despite decades of research, our understanding of the controls on bloom formation are poorly understood because the conditions antecedent to bloom formation are seldom characterized with the necessary temporal resolution; most nutrient monitoring programs sample too infrequently (weekly to monthly), and ad hoc bloom sampling is largely focused on blooms only after they have formed. In addition, chl a and nutrient concentrations can vary by an order of magnitude over diurnal time scales, and phytoplankton abundance is often strongly linked to the tidal phase (Fig. 2). To capture changing environmental conditions as blooms initiate, develop, and dissipate, we sampled the Lafayette River on a daily basis during late summer, when blooms are common, at the same portion of the tidal cycle for a period of $54 \mathrm{~d}$ in 2005. During this time, there were 2 dinoflagellate blooms and 1 diatom bloom. Sampling on a daily basis allowed for detailed observations regarding the sequence of events leading up to blooms as well as comparisons of phytoplankton abundance, ambient nutrient concentrations, and physical forcing (wind, precipitation, and spring-neap modulation of the tidal cycle) on timescales relevant to phytoplankton growth and bloom formation.

\section{Nutrient dynamics and climatological controls on the formation of blooms}

Nutrient loading because of precipitation and associated runoff and subsequent water column stratification play a key role in stimulating the formation of Cochlodinium polykrikoides blooms in the Lafayette River (Morse et al. 2011). Similarly, during the present study, precipitation and associated increases in ambient nutrient concentrations preceded the diatom and dinoflagellate blooms in late August and September, respectively (Figs. 3a,b \& 5a). Despite periods of intense rainfall prior to the start of this study, ambient nutrient concentrations were depleted at the start of this study, likely because the nutrient demand of a mixed bloom of Akashiwo sanguinea and Gymnodinium sp. already in progress was removing nutrients as quickly as they were supplied. A. sanguinea and Gymnodinium sp. are bloomforming dinoflagellates typical during the summer months in Chesapeake Bay and its tributaries (Marshall 1995, Marshall et al. 2005). Subsequent to this bloom, large increases in DIN concentrations were observed after rainfall events, and increases in phytoplankton biomass were generally associated with decreases in DIN. Following precipitation on August 22 to 23, nutrient concentrations increased by a factor of 5, and a diatom bloom dominated by Skeletonema costatum formed during a neap tide period (Figs. 3a \& 5a), rapidly drawing down dissolved $\mathrm{N}$ concentrations to the limit of detection (Fig. 3b). The relatively high wind speed at this time (Fig. 6a) may have contributed to the formation of a diatom rather 
than a dinoflagellate bloom since dinoflagellates typically thrive when wind-driven mixing and turbulence are low (Margalef 1978, Sellner et al. 2001, Smayda \& Reynolds 2001). Rain events associated with high nutrient inputs accompanied a frontal system associated with Hurricane Ophelia in mid-September. After this system passed, nutrient concentrations were high, the wind velocity decreased, and a dinoflagellate bloom ensued, likely because of high nutrient concentrations and decreased turbulence (Margalef 1978, Sellner et al. 2001, Cloern \& Dufford 2005). While nutrients were not depleted during this dinoflagellate bloom, the concentrations of both DIN and DON were reduced during the bloom, consistent with previous observations that many dinoflagellates are able to use organic nutrients (Graneli et al. 1999, Burkholder et al. 2008) to supplement their nutrition.

Subsequent to the diatom bloom at the end of August and the dinoflagellate bloom in September, there were numerous high-wind (but low-precipitation) events, and this resulted in low phytoplankton abundance, higher cyanobacterial abundance (Figs. 3a \& 5a), and the accumulation of $\mathrm{NH}_{4}{ }^{+}$and $\mathrm{NO}_{2}{ }^{-}$(Fig. 3b), likely because of $\mathrm{N}$ regeneration as bloom organisms settled and decayed, as well as incomplete nitrification, a process common during this time of the year (McCarthy et al. 1977, 1984, Horrigan et al. 1990). It is likely that regenerated nutrients were also contributed from benthic fluxes as high winds allow mixing of surface and bottom water and sediment resuspension in these shallow-water systems (Horrigan et al. 1990, Rizzo 1990). In September and early October, prior to and following the September dinoflagellate bloom, $\mathrm{NO}_{3}{ }^{-}$also accumulated in the water column, likely because of nitrification. At these times, cyanobacterial abundances were high relative to other phytoplankton taxa and picoplankton abundance was also higher at these times (Figs. 4a \& 5a). Cyanobacteria are important components of most phytoplankton communities and thrive under stratified conditions common in the summer, where they can take advantage of regenerated nutrient compounds (Paerl et al. 2006). Regenerated $\mathrm{N}$ is thought to fuel the bulk of primary production during summer months when new inputs of $\mathrm{N}$ are limited to stochastic events. Many dinoflagellate mixotrophs can also graze on picocyanobacteria including Synechococcus (Jeong et al. 2005, Burkholder et al. 2008), a common component of the cyanobacterial community in Chesapeake Bay (Marshall \& Nesius 1996, Chen et al. 2006), and picoplankton abundance was lowest during the September dinoflagellate bloom.
The Redfield ratio of carbon, N, and P nutrient elements in the environment has long been used to infer which nutrient is in shortest supply. Selection for or against diatoms has been associated with the supply of $\mathrm{SiO}_{4}{ }^{4-}$ relative to other nutrient elements (e.g. Si:N and/or Si:P ratios) (Conley \& Malone 1992, Smayda 1997). Justic et al. (1995) combined stoichiometric and absolute concentration criteria to assess the potential nutritional limitation of phytoplankton and defined $N$ limitation as DIN:P $<10$, Si:DIN $>1$, and total DIN $<1 \mu \mathrm{M}$. Similarly, P limitation was defined as DIN:P $>22$, Si:P $>22$, and $\mathrm{P}<0.1 \mu \mathrm{M}$ (Justic et al. 1995). During the present study period, the DIN:DIP ratio was $<10$ prior to September 15, indicative of potential $\mathrm{N}$ limitation, but DIN concentrations were only depleted $(<1 \mu \mathrm{M})$ during the first 2 blooms in August. After August 31, neither DIN nor DIP was depleted, and therefore it is unlikely that phytoplankton were limited by N or P during the remainder of the study (Justic et al. 1995). Similarly, throughout the duration of the study, the Si:DIN ratio was always $>1$, the Si:DIP ratio was always $>16$, and the minimum concentration of $\mathrm{Si}$ was $28.4 \mu \mathrm{M}$, suggesting that $\mathrm{SiO}_{4}{ }^{4-}$ concentrations were never limiting to diatom growth (Conley \& Malone 1992, Justic et al. 1995).

Estuarine environments are often N-limited systems (Howarth 2008); however, in contrast to our observations that $\mathrm{Si}$ and $\mathrm{P}$ were unlikely to limit productivity during our sampling period, monthly data from VADEQ's monitoring station in the Lafayette River (LFB01) (Fig. 1) suggest that $P$ might regulate productivity, at least seasonally. Between the years 2000 and 2009, chl $a$ and DIN concentrations at LFB01 showed some seasonality, with higher concentrations during spring and fall (Fig. $7 \mathrm{a}, \mathrm{C}$ ). In contrast, $\mathrm{PO}_{4}{ }^{3-}$ concentrations were highest between August and October in all years (Fig. 7b). While DIN and DIP concentrations were positively correlated (Pearson moment correlation, $t$-test, $\mathrm{p}<0.05$ ) at this station, chl a concentrations were positively correlated only with DIP (Pearson moment correlation, $t$-test, $\mathrm{p}<$ 0.001 ) and not DIN concentrations. It is important to remember that the VADEQ data are collected at a monthly interval and bi-weekly during the summer months; thus, the time interval is not particularly relevant to the life cycle of bloom organisms.

To explore these relationships further using data collected at a relevant timescale to bloom formation and because phytoplankton growth and bloom formation often lag nutrient inputs by several days, we calculated the time-lagged correlations between nutrient species and algal abundance from our data 

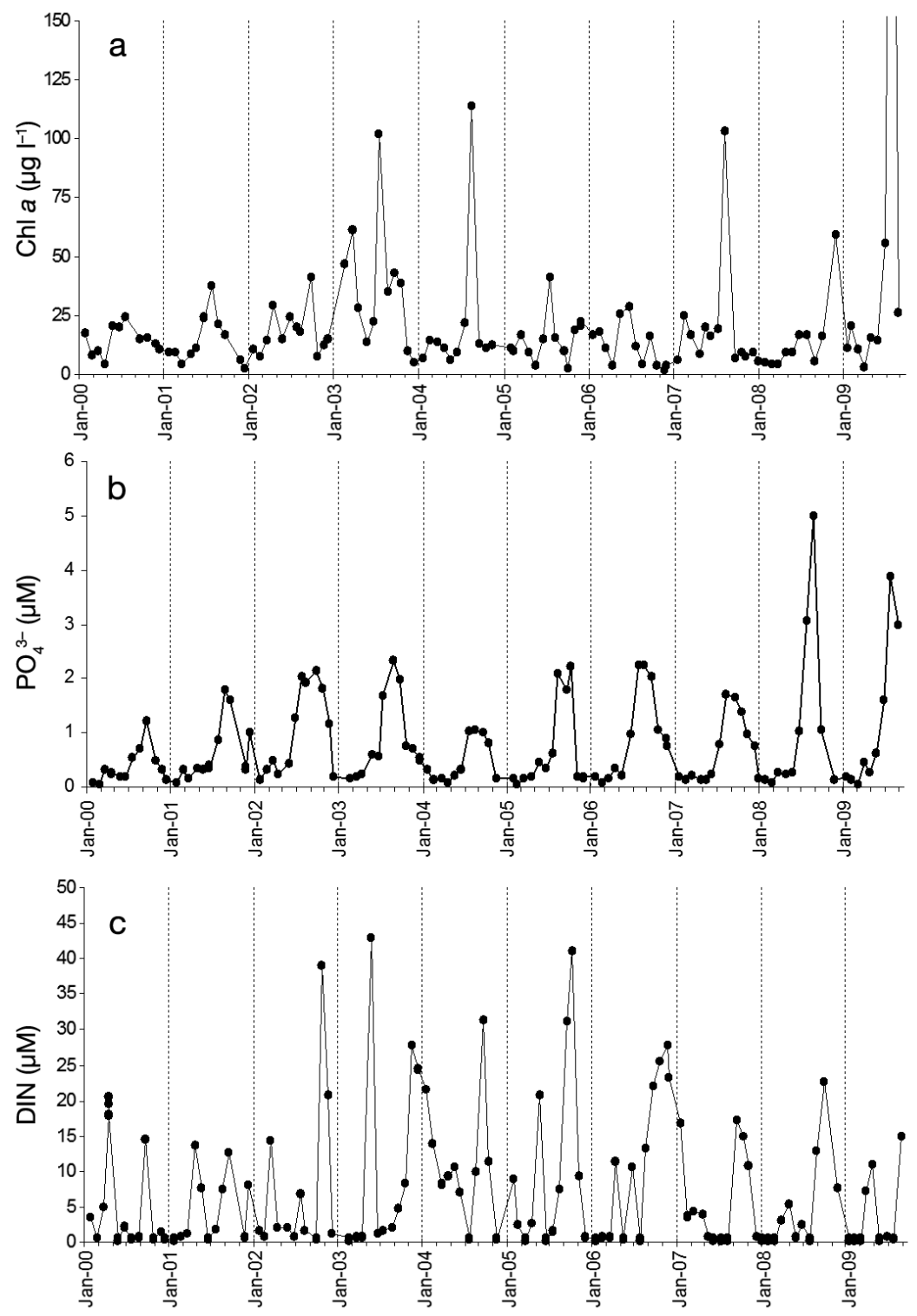

Fig. 7. Virginia Department of Environmental Quality water quality data showing (a) chl a $\left(\mu \mathrm{g} \mathrm{l}^{-1}\right)$, (b) $\mathrm{PO}_{4}{ }^{3-}(\mu \mathrm{M} \mathrm{P})$, and (c) dissolved inorganic nitrogen (DIN, $\mu \mathrm{M} N$ ), measured at station LFB01 between January 2000 and December 2009. Dates given as mo-yr. In (a), the value of the peak in August 2009 was $>300 \mathrm{\mu g} \mathrm{l}^{-1}$ and was caused by a Cochlodinium polykrikoides bloom (see Morse et al. 2013)

in the Lafayette River. To explore the effect of autocorrelation on nutrient concentrations (i.e. the serial correlation of a variable over time), the autocorrelation function of each nutrient compound was calculated for a $7 \mathrm{~d}$ period (Fig. 8a). All nutrient compounds showed some degree of autocorrelation, but $\mathrm{NO}_{3}{ }^{-}$and $\mathrm{PO}_{4}{ }^{-}$had the greatest amount, with positive autocorrelations exceeding the $95 \% \mathrm{CI}$ from 1 to $5 \mathrm{~d}$ forward in time (Fig. 8a), suggesting either a relatively steady source of these nutrients within the system or a lower removal rate compared to other nutrient compounds (e.g. lower uptake rates). $\mathrm{NH}_{4}{ }^{+}$concentrations showed the least amount of autocorrelation among measured nutrient compounds (Fig. 8a), with correlations exceeding the CI for $1 \mathrm{~d}$ forward in time only, suggesting variable concentrations of $\mathrm{NH}_{4}{ }^{+}$over time and enhanced removal rates compared to other nutrients, particularly given the high concentrations of $\mathrm{NH}_{4}{ }^{+}$ observed in mid- to late September.

To observe the effect of DIN concentrations on the abundance of different algal taxa, the cross-correlation function was calculated for DIN versus phytoplankton and cyanobacteria for $7 \mathrm{~d}$ in both forward and reverse time (Fig. 8b). DIN concentrations were strongly positively correlated with cumulative precipitation from $4 \mathrm{~d}$ in reverse time through $7 \mathrm{~d}$ in forward time, suggesting that DIN concentrations are tightly coupled to precipitation totals (Fig. 8b). DIN was negatively correlated with chl a concentrations at zero time lag and 1 to $2 \mathrm{~d}$ in reverse time and was positively correlated with dinoflagellate abundance from 3 to $7 \mathrm{~d}$ in forward time (Fig. 8b). To explore this relationship further, the cross-correlation function of dinoflagellate abundance versus nutrient compounds was plotted. There was a strong positive correlation (correlations exceeding the $95 \%$ CI) between dinoflagellate abundance and all $\mathrm{N}$ compounds from 2 to $7 \mathrm{~d}$ in reverse time (Fig. 8c). This suggests that when $\mathrm{N}$ concentrations increase, dinoflagellate abundance increased 2 to $7 \mathrm{~d}$ later, and likewise when $\mathrm{N}$ concentrations decrease, dinoflagellate abundance decreased accordingly. It is important to point out that correlation does not imply cause; however, because phytoplankton growth is dependent on nutrients and an increase in biomass requires $\mathrm{N}$ inputs, the increase in nutrient concentration likely caused the increase in dinoflagellate abundance.

The positive correlations between dinoflagellate abundance and all forms of measured $\mathrm{N}$ suggest that no particular nutrient species was required for bloom 

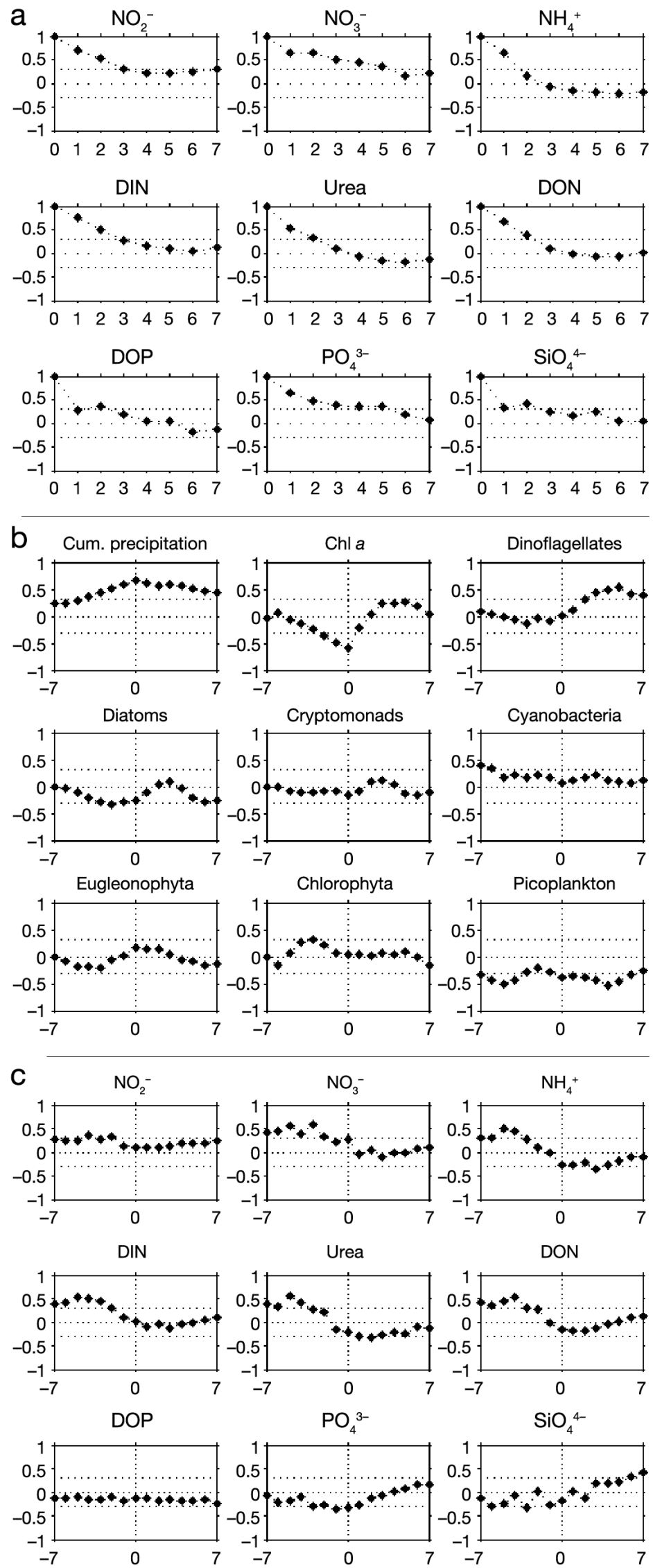

development but rather that the $\mathrm{N}$ concentration in general $\left(\mathrm{NO}_{3}{ }^{-}, \mathrm{NO}_{2}{ }^{-}, \mathrm{NH}_{4}{ }^{+}\right.$, urea, and DON), regardless of $\mathrm{N}$ species, was important. Dinoflagellates have been shown to be nutritionally flexible (Anderson et al. 2002, Burkholder et al. 2008), and they appear to thrive in eutrophic estuarine systems where there is variability in the form of $\mathrm{N}$ supplied.

While the positive-lagged correlation between $\mathrm{N}$ concentrations and dinoflagellate abundance may be indicative of growth stimulation by $\mathrm{N}$, the negative correlation between $\mathrm{PO}_{4}{ }^{3-}$ and dinoflagellate abundance with little to no lag may suggest that $P$ is drawn down during blooms to support cellular P demand and growth but is not growth limiting. Consistent with this observation, as dinoflagellate abundance increased during the September Gymnodinium sp. bloom, $\mathrm{PO}_{4}{ }^{+}$concentrations decreased by the largest amount observed during the study period, but $\mathrm{PO}_{4}{ }^{+}$was never depleted (Figs. 3a \& 4).

There was a strong positive correlation between diatom abundance and $\mathrm{PO}_{4}{ }^{+}$concentrations from 3 to $5 \mathrm{~d}$ in reverse time and a strong positive correlation with $\mathrm{SiO}_{4}{ }^{4-}$ concentrations from 2 to $3 \mathrm{~d}$ in reverse time (data not shown). Additionally, there was a strong negative correlation between diatom abundance and $\mathrm{NO}_{2}{ }^{-}$and DIN concentrations $2 \mathrm{~d}$ in forward time (data not shown). This suggests that diatom abundance increased in response to increases in $\mathrm{PO}_{4}{ }^{+}$and $\mathrm{SiO}_{4}{ }^{4-}$ concentrations, but when diatom abundance decreased, the concentrations of DIN and $\mathrm{NO}_{2}{ }^{-}$increased 2 d later, perhaps because of nutrient recycling following the collapse of the diatom bloom in early September.

Fig. 8. (a) Autocorrelation function of nutrient compounds measured at the Center for Coastal Physical Oceanography (CCPO). (b) Cross-correlation function of dissolved inorganic nitrogen (DIN) versus environmental variables and phytoplankton taxa at CCPO, (c) Cross-correlation function of dinoflagellate abundance versus nutrient compounds at CCPO. A $7 \mathrm{~d}$ forward time lag is shown along the $x$-axis in (a), with Day 0 being the present (i.e. no time lag), and a $7 \mathrm{~d}$ forward and reverse time lag is shown along the $x$-axis in (b) and (c). In all plots, the correlation coefficient at each time lag is shown along the $y$-axis, with the $95 \% \mathrm{CI}$ for correlations shown as dashed lines. DON: dissolved organic nitrogen; DOP: dissolved organic phosphorus, $\mathrm{NH}_{4}^{+}$: ammonium; $\mathrm{SiO}_{4}{ }^{-4}$ : silicate 
The high concentrations of $\mathrm{NO}_{2}^{-}$observed during the present study and the importance of $\mathrm{NO}_{2}{ }^{-}$to bloom formation suggest that $\mathrm{NO}_{2}{ }^{-}$may play a larger role in estuarine environments than previously believed. The uptake of $\mathrm{NO}_{2}{ }^{-}$is well documented in oceanic environments, where it can be an important source of N (Collos 1998, Lomas \& Lipschultz 2006). While McCarthy et al. $(1977,1984)$ reported high $\mathrm{NO}_{2}{ }^{-}$concentrations (up to $10 \mu \mathrm{M}$ ) in Chesapeake Bay and speculated that $\mathrm{NO}_{2}{ }^{-}$was derived from incomplete nitrification associated with destratification and mixing of surface and bottom waters, the abundance and utilization of this $\mathrm{N}$ source has not been widely examined in most estuarine systems. Concentrations of $\mathrm{NO}_{2}{ }^{-}$were observed that were consistent with those reported for Chesapeake Bay (McCarthy et al. 1977) and in the York River (L. Killberg \& D. Bronk unpubl. data). $\mathrm{NO}_{2}{ }^{-}$can be formed during incomplete nitrification and be released by phytoplankton during $\mathrm{NO}_{3}{ }^{-}$uptake and less commonly during incomplete denitrification (Zehr \& Ward 2002, Lomas \& Lipschultz 2006). Because the process of nitrification is carried out by 2 separate groups of organisms, ammonium-oxidizing bacteria (AOB) and/or ammonium-oxidizing archaea (AOA) and nitrite-oxidizing bacteria (NOB) (Zehr and Ward 2002, Ward et al. 2007), the process of nitrification can become uncoupled, and $\mathrm{NO}_{2}^{-}$may accumulate in the water column (McCarthy et al. 1984). AOB are abundant throughout Chesapeake Bay, with the highest diversity in the oligohaline upper bay region (Ward et al. 2007). In the polyhaline portion of the bay, AOA may be the dominant nitrifiers (Wuchter et al. 2006, Ward et al. 2007). Based on the tight coupling of $\mathrm{NO}_{2}{ }^{-}$and $\mathrm{NH}_{4}{ }^{+}$concentrations, the low $\mathrm{NO}_{3}{ }^{-}$ concentrations prior to mid-September (Fig. 3b), and the presence of sufficient oxygen in the water column (data not shown), the accumulation of high $\mathrm{NO}_{2}^{-}$ concentrations in the present study was likely a result of incomplete nitrification. This may occur when populations of AOB and NOB become de-coupled over space and time.

\section{Physical controls on phytoplankton community dynamics}

Wind-driven mixing in shallow estuaries can both inject nutrients from the benthos (Rizzo 1990) and result in the demise (Morse et al. 2011) or dissipation of algal biomass (Figs. 3a,b \& 6a). Although the Lafayette River is generally sheltered from the wind, wind speed and direction may be important factors controlling taxonomic dominance and bloom development. For example, during a period of low and variable winds (August 28 to 30), phytoplankton biomass was high, and cryptophytes and diatoms were both abundant (Figs. 3a,c \& 6a). However, following a period of high winds from the southwest (Fig. 6a), diatom abundance increased while cryptophyte abundance decreased drastically (Fig. 3a,c). The increase in wind velocity likely mixed the entire water column in the shallow Lafayette River, causing particle resuspension including diatoms, sediments, and other passive particles and creating unfavorable conditions for flagellates.

Following Hurricane Katrina, a high-pressure system in the region resulted in an extended period of high winds $\left(>7 \mathrm{~m} \mathrm{~s}^{-1}\right)$ from the northeast. This type of atmospheric system forces oceanic water landward, resulting in decreased riverine flushing, accumulation of oceanic water in Chesapeake Bay, positive tidal residuals at Sewell's Point, and saltwater intrusion into the Lafayette River. Chesapeake Bay and its tributaries are more vulnerable to northeasterly winds because of the fetch over which they develop and the north-south orientation of the bay mouth. The combined wind-driven and tidal mixing caused by this high-pressure system likely contributed to the decreased algal biomass observed during this period (Figs. 3a \& 6a).

In contrast, winds from the southwest typically result in enhanced riverine flushing and offshore transport of water through the bay mouth. The Lafayette River is sheltered from the southwesterly winds by the landmass; thus, the effects of high wind from this direction are reduced. Therefore, although the winds were strong between August 30 and September 2, the winds were from the southwest and so did not result in the same degree of mixing and turbulence in the system, while allowing nutrient inputs from mixing to stimulate diatom growth. Diatoms characteristically thrive better in higher energy environments than dinoflagellates (Margalef 1978, Smayda \& Reynolds 2001, Huisman et al. 2004). In contrast, the high-pressure system that dominated from September 4 through 9 resulted in northeasterly winds that resulted in a large oceanic influence on the lower Chesapeake Bay and its subtributaries, including the Lafayette River. Salinity in the Lafayette increased, there was a high positive tidal residual during this period, phytoplankton abundance decreased, and DIP concentrations decreased despite the lower algal biomass, suggesting increased turbidity and particle-associated nutrient removal (Froelich 1988). 


\section{Timescales of variability important to phytoplankton}

One of the problems associated with sampling blooms is coping with estuarine variability on timescales ranging from minutes to months and biological variability associated with the lifecycles and behavior of phytoplankton cells and populations (Hubertz \& Cahoon 1999, Lucas et al. 2006, Glibert et al. 2008). Within a $24 \mathrm{~h}$ period of fixed-station sampling, nutrient concentrations and phytoplankton abundance varied by an order of magnitude, and nutrient and chl a concentrations were strongly linked to the tidal cycle (Fig. 2), as had been observed in this system previously (M. R. Mulholland et al. unpubl.). Shallow estuaries and coastal systems are highly dynamic areas where a multitude of physical, chemical, and biological factors concomitantly influence the distribution, growth, and transport of the phytoplankton community, which in turn modify the nutrient regimes of the surrounding waters. This variability makes it difficult to understand controls on blooms using data collected during most long-term monitoring programs that may sample systems only at weekly to monthly intervals, a frequency insufficient to capture ephemeral blooms. The tidal control of biomass and nutrient concentrations in estuarine environments has direct implications for interpreting monitoring data that are not tidally resolved (Cloern 1991, Lucas et al. 1999). In addition, it is now known that stochastic events are important for controlling nutrient inputs during large parts of the year, and these affect nutrient loading from the water- and airsheds as well as nutrient inputs from the benthos (Paerl 1997).

When daily measurements of chl a concentrations from the present study are compared to chl a concentrations measured monthly at LFB01 (Fig. 1), it is apparent that short-term variability is missed in the monthly sampling record. In addition, when chl a concentrations are compared at the 2 sites $(<1 \mathrm{~km}$ apart) on the same date in August, a factor of 2 difference is observed between the sites, highlighting the often patchy spatial distribution of chl a in these tidally dominated systems. While the VADEQ chl a monitoring record between 1999 and 2009 includes periods of high chl a concentrations in the Lafayette River, the magnitude of these peaks is far less than those measured during targeted studies of blooms (Mulholland et al. 2009, Morse et al. 2011). It is important to remember that the Chesapeake Bay monitoring program and associated sampling by VADEQ was not and is not designed to capture the dynamics of ephemeral blooms but rather was designed as a statewide effort to understand long-term changes in Chesapeake Bay phytoplankton communities. A wide suite of methods, including in situ monitoring devices, remote sensing, and targeted sampling at a high temporal frequency, can be used to supplement long-term monitoring systems, such as those in place in Chesapeake Bay, to fully capture the dynamics associated with algal populations in stochastic estuarine ecosystems. To this end, continuous monitoring of nutrients and chl a provides a much more exhaustive and complete view of estuarine dynamics, but these data sets are still limited (Glibert et al. 2008). In addition, most long-term monitoring programs do not collect tidally resolved data. Timing sampling to a specific portion of the tidal cycle may help to resolve processes occurring at least at tidal time scales. With the advent of technologies such as in situ monitoring devices (e.g. Lucas et al. 2006) and in situ nutrient analyzers (e.g. Glibert et al. 2008), targeted sampling aimed at understanding conditions promoting the initiation of blooms will become easier. However, integrating the complex coupled climatological, physical, and biological forcings associated with blooms is likely to remain a challenge into the future.

Acknowledgements. This research was supported by NSF grant IOS-0517542 to M.R.M. and H.G.M. We thank P. Bernhardt and K. C. Filippino for lab support and J. Jackson for help with the $24 \mathrm{~h}$ sampling event. We also thank the editors and 3 anonymous reviewers for helping to increase the value of this manuscript.

\section{LITERATURE CITED}

Affronti LF, Marshall HG (1994) Using frequency of dividing cells in estimating autotrophic picoplankton growth and productivity in the Chesapeake Bay. Hydrobiologia 284: 193-203

Anderson DM, Glibert PM, Burkholder JM (2002) Harmful algal blooms and eutrophication: nutrient sources, composition, and consequences. Estuaries 25:704-726

Anderson DM, Burkholder JM, Cochlan WP, Glibert PM and others (2008) Harmful algal blooms and eutrophication: examining linkages from selected coastal regions of the United States. Harmful Algae 8:39-53

Box GEP, Jenkins GM, Reinsel GC (2008). Time series analysis: forecasting and control, 4th edn. Wiley, New York, NY

Burkholder JM, Glibert PM, Skelton HM (2008) Mixotrophy, a major mode of nutrition for harmful algal species in eutrophic waters. Harmful Algae 8:77-93

Chen F, Wang K, Kan J, Suzuki MT, Wommack KE (2006) Diverse and unique picocyanobacteria in Chesapeake Bay, revealed by 16S-23S rRNA internal transcribed spacer sequences. Appl Environ Microbiol 72:2239-2243 
Chesapeake Bay Program (2009) Water quality database. Available at www.chesapeakebay.net/data_waterquality. aspx (accessed 13 May 2009)

Cloern JE (1991) Tidal stirring and phytoplankton bloom dynamics in an estuary. J Mar Res 49:203-221

Cloern JE, Dufford R (2005) Phytoplankton community ecology: principles applied in San Francisco Bay. Mar Ecol Prog Ser 285:11-28

Cloern JE, Cole, BE, Wong RLJ, Alpine AE (1985) Temporal dynamics of estuarine phytoplankton: a case study of San Francisco Bay. Hydrobiologia 129:153-176

> Cloern JE, Powell TM, Huzzey LM (1989) Spatial and temporal variability in south San Francisco Bay (USA). II. Temporal changes in salinity, suspended sediments, and phytoplankton biomass and productivity over tidal time scales. Estuar Coast Shelf Sci 28:599-613

> Collos Y (1998) Nitrate uptake, nitrite release and uptake, and new production estimates. Mar Ecol Prog Ser 171: 293-301

> Conley DJ, Malone TC (1992) Annual cycle of dissolved silicate in Chesapeake Bay: implications for the production and fate of phytoplankton biomass. Mar Ecol Prog Ser 81: 121-128

Cooper SR, Brush GS (1991) Long-term history of Chesapeake Bay anoxia. Science 254:992-996

Cooper SR, Brush GS (1993) A 2,500-year history of anoxia and eutrophication in Chesapeake Bay. Estuaries 16: 617-626

Dauer DM, Marshall HG, Carpenter KE, Donat JR, Lane MF, Doughten S, Hoffman FJ (2005) Status and trends in water quality and living resources in the Virginia Chesapeake Bay: James River (1985-2004). Final report to the Virginia Department of Environmental Quality. Old Dominion University, Norfolk, VA

> Dustan P, Pinckney JL (1989) Tidally induced estuarine phytoplankton patchiness. Limnol Oceanogr 34:410-419

Froelich PN (1988) Kinetic control of dissolved phosphate in natural rivers and estuaries: a primer on the phosphate buffer mechanism. Limnol Oceanogr 33:649-668

Geyer WR, Signell RP (1992) A reassessment of the role of tidal dispersion in estuaries and bays. Estuaries 15: 97-108

Glibert PM, Kelly V, Alexander J, Codispoti LA, Boicourt WC, Trice TM, Michael B (2008) In situ nutrient monitoring: a tool for capturing nutrient variability and the antecedent conditions that support algal blooms. Harmful Algae 8:175-181

> Gobler CJ, Lonsdale DJ, Boyer GL (2005) A review of the causes, effects, and potential management of harmful brown tide blooms caused by Aureococcus anophagefferens (Hargraves et Sieburth). Estuaries 28:726-749

Graneli E, Carlsson P, Legrand C (1999) The role of C, N and $\mathrm{P}$ in dissolved organic matter as a nutrient source for phytoplankton growth, including toxic species. Aquat Ecol 33:17-27

- Heil CA, Glibert PM, Al-Sarawi MA, Faraj M, Behbehani M, Husain M (2001) First record of a fish-killing Gymnodinium sp. bloom in Kuwait Bay, Arabian Sea: chronology and potential causes. Mar Ecol Prog Ser 214:15-23

> Heisler J, Glibert PM, Burkholder JM, Anderson DM and others (2008) Eutrophication and harmful algal blooms: a scientific consensus. Harmful Algae 8:3-13

$>$ Hodgkiss IJ, Ho KC (1997) Are changes in N:P ratios in coastal waters the key to increased red tide blooms? Hydrobiologia 352:141-147
Horrigan SG, Montoya JP, Nevins JL, McCarthy JJ, Ducklow H, Goericke R, Malone T (1990) Nitrogenous nutrient transformations in the spring and fall in the Chesapeake Bay. Estuar Coast Shelf Sci 30:369-391

> Howarth RW (2008) Coastal nitrogen pollution: a review of sources and trends globally and regionally. Harmful Algae 8:14-20

> Hubertz ED, Cahoon LB (1999) Short-term variability of water quality parameters in two shallow estuaries of North Carolina. Estuaries 22:814-823

Huisman J, Sharples J, Stroom JM, Visser PM, Kardinaal WEA, Verspagen JMH, Sommeijer B (2004) Changes in turbulent mixing shift competition for light between phytoplankton species. Ecology 85:2960-2970

> Jeong HJ, Park JY, Nho JH, Park MO and others (2005) Feeding by red-tide dinoflagellates on the cynanobacterium Synechococcus. Aquat Microb Ecol 41:131-143

> Justic D, Rabalais NN, Turner RE, Dortch Q (1995) Changes in nutrient structure of river-dominated coastal waters: stoichiometric nutrient balance and its consequences. Estuar Coast Shelf Sci 40:339-356

> Kemp WM, Boynton WR, Adolf JE, Boesch DF and others (2005) Eutrophication of Chesapeake Bay: historical trends and ecological interactions. Mar Ecol Prog Ser 303:1-29

Li Y, Smayda TJ (2001) A chlorophyll time series for Narragansett Bay: assessment of the potential effect of tidal phase on measurement. Estuaries 24:328-336

Lomas MW, Lipschultz F (2006) Forming the primary nitrite maximum: Nitrifiers or phytoplankton? Limnol Oceanogr 51:2453-2467

> Lomas MW, Glibert PM, Clougherty DA, Huber DR, Jones J, Alexander J, Haramoto E (2001) Elevated organic nutrient ratios associated with brown tide algal blooms of Aureococcus anophagefferens (Pelagophyceae). J Plankton Res 23:1339-1344

> Lucas LV, Koseff JR, Monismith SG, Cloern JE, Thompson JK (1999) Processes governing phytoplankton blooms in estuaries. II: The role of horizontal transport. Mar Ecol Prog Ser 187:17-30

Lucas LV, Sereno DM, Bureu JR, Schraga TS and others (2006) Intradaily variability of water quality in a shallow tidal lagoon: mechanisms and implications. Estuar Coast 29:711-730

> Mallin MA, Eshem EC, Williams KE, Nearhoof JE (1999) Tidal stage variability of fecal coliform and chlorophyll $a$ concentrations in coastal creeks. Mar Pollut Bull 38: 414-422

Margalef R (1978) Life-forms of phytoplankton as survival alternatives in an unstable environment. Oceanol Acta 1: 493-509

Marshall HG (1995) Succession of dinoflagellate blooms in the Chesapeake Bay USA. In: Lassus P, Arzul G, ErardLe Denn E, Gentien P, Marcillou-Le Baut M (eds) Harmful marine algal blooms. Lavoisier, Paris, p 615-620

Marshall HG, Nesius KK (1996) Phytoplankton composition in relation to primary production in Chesapeake Bay. Mar Biol 125:611-617

Marshall HG, Burchardt L, Lacouture R (2005) A review of phytoplankton composition within Chesapeake Bay and its tidal tributaries. J Plankton Res 27:1083-1102

- Marshall HG, Lane MF, Nesius KK, Burchardt L (2009) Assessment and significance of phytoplankton species composition within Chesapeake Bay and Virginia tributaries through a long-term monitoring program. Environ 
Monit Assess 150:143-155

McCarthy JJ, Taylor WR, Taft JL (1977) Nitrogenous nutrition of the plankton in the Chesapeake Bay. 1. Nutrient availability and phytoplankton preferences. Limnol Oceanogr 22:996-1011

McCarthy JJ, Kaplan W, Nevins JL (1984) Chesapeake Bay nutrient and plankton dynamics. 2. Sources and sinks of nitrite. Limnol Oceanogr 29:84-98

Morse RE, Shen J, Blanco-Garcia JL, Hunley WS, Fentress S, Wiggins M, Mulholland MR (2011) Environmental and physical controls on the formation and transport of blooms of the dinoflagellate Cochlodinium polykrikoides Margalef in the lower Chesapeake Bay and its tributaries. Estuar Coast 34:1006-1025

- Morse RE, Mulholland MR, Hunley WS, Fentress S, Wiggins M, Blanco-Garcia JL (2013) Controls on the initiation and development of blooms of the dinoflagellate Cochlodinium polykrikoides Margalef in lower Chesapeake Bay and its tributaries. Harmful Algae 28:71-82

Mulholland MR, Morse RE, Boneillo GE, Bernhardt PW and others (2009) Understanding causes and impacts of the dinoflagellate, Cochlodinium polykrikoides, blooms in the Chesapeake Bay. Estuar Coast 32:734-747

Paerl HW (1988) Nuisance phytoplankton blooms in coastal, estuarine, and inland waters. Limnol Oceanogr 33: 823-847

Paerl HW (1997) Coastal eutrophication and harmful algal blooms: importance of atmospheric deposition and groundwater as 'new' nitrogen and other nutrient sources. Limnol Oceanogr 42:1154-1165

Paerl HW, Valdes LM, Peirls BL, Adolf JE, Harding LW Jr (2006) Anthropogenic and climatic influences on the eutrophication of large estuarine ecosystems. Limnol Oceanogr 51:448-462

Parsons TR, Maita Y, Lalli CM (1984) A manual of chemical and biological methods for seawater analysis. Pergamon Press, Oxford

Pinckney JL, Paerl HW, Tester P, Richardson TL (2001) The role of nutrient loading and eutrophication in estuarine ecology. Environ Health Perspect 109:699-706

Rizzo WM (1990) Nutrient exchanges between the water column and a subtidal benthic microalgal community. Estuaries 13:219-226

Sellner KG, Sellner SG, Lacouture RV, Magnien RE (2001) Excessive nutrients select for dinoflagellates in the strat-

Editorial responsibility: Katherine Richardson, Copenhagen, Denmark ified Patapsco River estuary: Margalef reigns. Mar Ecol Prog Ser 220:93-102

Shen J, Boon JD, Kuo AY (1999) A modeling study of a tidal intrusion front and its impact on larval dispersion in the James River estuary, Virginia. Estuaries 22:681-692

Smayda TJ (1990) Novel and nuisance phytoplankton blooms in the sea: evidence for a global epidemic. In: Graneli E, Sundström B, Edler L, Anderson DM (eds) Toxic marine phytoplankton: proceedings of the Fourth International Conference on Toxic Marine Phytoplankton, held June 26-30, 1989, in Lund, Sweden. Elsevier, New York, NY, p 29-40

Smayda TJ (1997) Harmful algal blooms: their ecophysiology and general relevance to phytoplankton blooms in the sea. Limnol Oceanogr 42:1137-1153

Smayda TJ, Reynolds CS (2001) Community assembly in marine phytoplankton: application of recent models to harmful dinoflagellate blooms. J Plankton Res 23: $447-461$

Solorzano L (1969) Determination of ammonia in natural waters by the phenolhypochlorite method. Limnol Oceanogr 14:799-801

- Sunda WG, Graneli E, Gobler CJ (2006) Positive feedback and the development and persistence of ecosystem disruptive algal blooms. J Phycol 42:963-974

Trigueros JM, Orive E (2000) Tidally driven distribution of phytoplankton blooms in a shallow, macrotidal estuary. J Plankton Res 22:969-986

Ward BB, Eveillard D, Kirshtein JD, Nelson JD, Voytek MA, Jackson GA (2007) Ammonia-oxidizing bacterial community composition in estuarine and oceanic environments assessed using a functional gene microarray. Environ Microbiol 9:2522-2538

Welschmeyer NA (1994) Fluorometric analysis of chlorophyll $a$ in the presence of chlorophyll $b$ and pheopigments. Limnol Oceanogr 39:1985-1992

White EG (1972). A physical hydrographic study of the Lafayette River. MS thesis, Old Dominion University, Norfolk, VA

> Wuchter C, Abbas B, Coolen MJL, Herfort L and others (2006) Archaeal nitrification in the ocean. Proc Natl Acad Sci USA 103:12317-12322

Zehr JP, Ward BB (2002) Nitrogen cycling in the ocean: new perspectives on processes and paradigms. Appl Environ Microbiol 68:1015-1024

Submitted: May 27, 2013; Accepted: January 27, 2014

Proofs received from author(s): April 1, 2014 